\title{
Toxicological effects induced by the nanomaterials fullerene and nanosilver in the polychaeta Laeonereis acuta (Nereididae) and in the bacteria communities living at their surface
}

\author{
Bianca Fell Marques ${ }^{a, b}$, Lucas Freitas Cordeiro ${ }^{a, b}$, Luiza Wilges Kist ${ }^{c}$, \\ Maurício Reis Bogo c,d, Gerardo López ${ }^{\mathrm{e}, \mathrm{f}}$, Gisela Pagano ${ }^{\text {e,f }}$, Diana Tomazi Muratt ${ }^{\mathrm{g}}$, \\ Leandro Machado de Carvalho ${ }^{\mathrm{g}}$, Irene Clemes Külkamp-Guerreiro ${ }^{\mathrm{h}}$, \\ José M. Monserrat ${ }^{\mathrm{a}, \mathrm{b}, \mathrm{i}, *}$ \\ a Instituto de Ciências Biológicas (ICB), Universidade Federal do Rio Grande - FURG, Rio Grande, Brazil \\ b Programa de Pós-Graduação em Ciências Fisiológicas - Fisiologia Animal Comparada, Universidade Federal de Rio Grande - FURG, Rio Grande, Brazil \\ ${ }^{\mathrm{c}}$ Laboratório de Biologia Genômica e Molecular, Faculdade de Biociências, Pontifícia Universidade Católica do Rio Grande do Sul, Avenida Ipiranga 6681, \\ 90619-900 Porto Alegre, RS, Brazil \\ ${ }^{\mathrm{d}}$ Instituto Nacional de Ciência e Tecnologia Translacional em Medicina (INCT-TM), 90035-003 Porto Alegre, RS, Brazil \\ e Nanotek S.A., Argentina \\ ${ }^{\mathrm{f}}$ Universidad Tecnológica Nacional, Santa Fe, Argentina \\ ${ }^{\mathrm{g}}$ Departamento de Química, Universidade Federal de Santa Maria (UFSM), Santa Maria, Brazil \\ ${ }^{\mathrm{h}}$ Faculdade de Farmácia, Universidade Federal do Rio Grande do Sul (UFRGS), Porto Alegre, RS, Brazil \\ ${ }^{\mathrm{i}}$ Instituto Nacional de Ciência e Tecnologia Nanomateriais de Carbono, Belo Horizonte, MG, Brazil
}

\section{A R T I C L E I N F O}

\section{Article history:}

Received 14 February 2013

Received in revised form

2 May 2013

Accepted 4 May 2013

\section{Keywords:}

Fullerene

Nanosilver

Nanotoxicology

Polychaete

Bacteria communities

\begin{abstract}
A B S T R A C T
Fullerene $\left(\mathrm{nC}_{60}\right)$ and nanosilver $(\mathrm{nAg})$ are nanomaterials with bactericide properties. The increments in their use raise questions about their potential environmental impacts, including estuarine ones. The polychaete Laeonereis acuta (Nereididae) secretes mucus that is colonized by bacteria communities. We analyzed the antioxidant and oxidative damage responses of anterior, middle and posterior region of L. acuta and bacteria communities after $\mathrm{nC}_{60}$ or $\mathrm{nAg}$ exposure during $24 \mathrm{~h}$. Molecular analysis showed a prevalence of Vibrio genera in the communities. Bacteria biomass was lowered in worms exposed to $1.0 \mathrm{mg} / \mathrm{L}$ of $\mathrm{nAg}$. $\mathrm{nC}_{60}$ reduced total antioxidant capacity of bacteria from worms exposed to $0.1 \mathrm{mg} / \mathrm{L}$. Worms anterior region presented lower antioxidant capacity after exposure to $1.0 \mathrm{mg} \mathrm{nC} 60 / \mathrm{L}$, and the same was observed in the posterior region of worms exposed to $1.0 \mathrm{mg} \mathrm{nAg} / \mathrm{L}$. Lipid peroxidation was reduced in the anterior region of worms exposed to $\mathrm{nC}_{60}$ and the opposite was observed in the posterior region.
\end{abstract}

(C) 2013 Elsevier Ltd. All rights reserved.

\section{Introduction}

It is clear that the development of nanotechnologies offer several benefits to the society. At present, manufactured nanomaterials (NM) are used in a variety of commercial and industrial applications (Li et al., 2010; Oberholster et al., 2011). However, it is not clear the potential risks elicited by NM in human and environment health (Kahru and Dubourguier, 2010). As a consequence

\footnotetext{
* Corresponding author. Instituto de Ciências Biológicas (ICB), Universidade Federal do Rio Grande - FURG, Cx. P. 474, CEP 96.200-970, Rio Grande, RS, Brazil. Tel.: +55 5332935196 .

E-mail addresses: josemmonserrat@pesquisador.cnpq.br, josemmonserrat@ pq.cnpq.br (J.M. Monserrat).
}

several nanotoxicology studies in the last years have evaluated the deleterious effects induced by NM in biological systems, including molecular, cellular, organs and in vivo responses (Zhao et al., 2005; Baun et al., 2008; Azevedo Costa et al., 2012).

Fullerenes are a family of NM constituted exclusively by carbon atoms. The simplest member of this family and the most common fullerene known is $C_{60}$ (Farré et al., 2011). Probably the most environmentally relevant form of $\mathrm{C}_{60}$ is the fullerene water suspension ( $\mathrm{nC}_{60}$ ) (Fortner et al., 2005), which can be formed in water either through extensive stirring of $\mathrm{C}_{60}$ powder or by employing organic solvents (Lyon et al., 2006). However, previous evidences showed that preparation of fullerene suspensions with organic solvents like tetrahydrofuran (THF) induced toxic responses that were mainly related to degradation products of these solvents (Zhu 
et al., 2006; Henry et al., 2007). The toxicity mechanism of $\mathrm{nC}_{60}$ has generally been attributed to its ability to generate reactive oxygen species (ROS) when photosensitized (Kamat et al., 2000; Shinohara et al., 2009), although other studies have reported bactericidal effects through a ROS-independent mechanism (Lyon and Alvarez, 2008; Lyon et al., 2008; Trpkovic et al., 2012). Bactericidal effects of fullerene in Bacteria subtilis were reported by Lyon et al. (2006), a result that was enhanced by the use of an organic solvent (tetrahydrofuran, THF) to prepare the fullerene suspension. Oberdörster (2004) showed that $\mathrm{nC}_{60}$ suspensions prepared with the organic solvent tetrahydrofuran (THF) induced lipid peroxidation in brains of Micropterus salmoides fish. Zhu et al. (2008) showed that fullerene aggregates, suspended in water after long-term stirring, induced higher lipid peroxides levels in Carassius auratus fish and augmented the activity of the antioxidant enzyme superoxide dismutase.

As cited above, Lyon and Alvarez (2008) proposed that the $\mathrm{nC}_{60}$ exerts ROS-independent oxidative stress in bacteria. Another study using phospholipid fatty acid analysis (PLFA) showed no evidence of lipid peroxidation in bacteria exposed to $\mathrm{nC}_{60}$ (Fang et al., 2007). Furthermore, Lyon and Alvarez (2008) postulated that $\mathrm{nC}_{60}$ is a NM that exerts toxicity as a particle via a chemical interaction upon direct contact with the bacteria. However, data on the oxidizing properties and biological action of fullerenes are contradictory, indicating the need of scientific information for the safe use of nanotechnology.

Nanosilver ( $\mathrm{nAg}$ ) is one of the engineered NM most commonly used in consumer products (Marambio-Jones and Hoek, 2010). This NM posses an exceptional bactericidal activity with a relatively low production cost (Fabrega et al., 2011). According to Marambio-Jones and Hoek (2010) some of the toxicity mechanisms elicited by $\mathrm{nAg}$ include, between others: (1) release of silver ions, generating ROS; (2) interaction with membrane proteins affecting their function; (3) accumulation in the cell membrane, affecting membrane permeability. In fact, a study of the toxicity effects of different silver forms on nitrifying bacteria showed that not only $\mathrm{Ag}^{+}$and $\mathrm{AgCl}$, but also $\mathrm{nAg}$ are able to induce intracellular ROS generation (Choi et al., 2008).

The predicted concentration of $\mathrm{nAg}$ in the aquatic environment is estimated to be about $0.01 \mu \mathrm{g} / \mathrm{L}$ (Tiede et al., 2009), but given the increasing number of applications, the discharge of nAg will undoubtedly increase in the near future (Bilberg et al., 2011). The study of Bradford et al. (2009) observed that tanks containing sediment and estuarine water exposed to $1000 \mu \mathrm{g} / \mathrm{L}$ of silver nanoparticles presented high water silver concentration after dosing during 20 days. However the authors registered silver accumulation in sediments after 10 days where no further adding of silver nanoparticles was performed, indicating that this NM was transported from the water to the sediment layer. This behavior points to benthic invertebrates as unintended targets of NM (Oberholster et al., 2011).

The polychaete Laeonereis acuta is a selective deposit feeder, living in close contact with the sediment (Raes and Vanreusel, 2006). Moraes et al. (2006) registered high total antioxidant competence against peroxyl and hydroxyl radicals in the mucus of this species that showed to be colonized by rod-shape bacteria. Authors considered that mucus from $L$. acuta should be a good substrate for the growth of bacteria communities that, in turn, could augment the antioxidant defense of the worm. Ferreira-Cravo et al. (2007) reported that ROS concentration and total antioxidant capacity showed a body gradient in L. acuta, where a lower ROS concentration was observed in the anterior region (first 20 settiger segments), augmenting in the middle (next 20 settiger segments) and posterior regions (rest of the body).

Taking into account the cited information, the objective of this study was to evaluate the antioxidant and oxidative damage responses induced by $\mathrm{nC}_{60}$ and $\mathrm{nAg}$ on different body regions of the polychaeta and on bacteria communities living at the mucus secretion of this organism. The study considered the toxicological responses induced by an organic $\left(\mathrm{nC}_{60}\right)$ and inorganic $(\mathrm{nAg})$ on bacteria associated to $L$. acuta in virtue of the important antioxidant role that these communities play (Moraes et al., 2006). Other kind of biological interactions have been described by Stabili et al. (2011), that reported lysozyme-like activity in the mucus of the polychaeta Sabella spallanzanii to different bacteria genera. Considering the facts cited above, it was hypothesized that NM possessing bactericidal activity as $\mathrm{nC}_{60}$ and $\mathrm{nAg}$ should affect the bacteria communities living on $L$. acuta, with consequences in terms of antioxidant and oxidative damage responses.

\section{Materials and method}

\subsection{Fullerene solution preparation and characterization}

Previous evidences showed that preparation of fullerene stock solution with organic solvents induced toxicity related to degradation products of these solvents (Zhu et al., 2006). Because of these, an aqueous fullerene suspension $\left(\mathrm{nC}_{60}\right)(200 \mathrm{mg} / \mathrm{L} ; \mathrm{SES}$ Research, $99 \%$ purity) was prepared by the constant stirring of $\mathrm{C}_{60}$ in Milli $\mathrm{Q}$ water during two months (photoperiod: $24 \mathrm{~L}$ ). This methodology produced a yellow-brownish suspension that, according to Andrievsky et al. (2005), is typical of a highly stable aqueous molecule-colloidal solution of fullerenes that contain single hydrated fullerenes and labile clusters. It is also important to note that this procedure has been used in previous studies from our group (Letts et al., 2011; Azevedo Costa et al., 2012; Ferreira et al., 2012; Socoowski Britto et al., 2012). The aqueous suspension was sequentially filtered through 0.45 and $0.20 \mu \mathrm{m}$ filters (Millipore). Fullerene concentration was estimated by measuring total carbon concentration with a TOC-V CPH (Shimadzu) total organic carbon analyzer. Suspensions of fullerene were characterized using a JEOL JSM 1200 EX II transmission electron microscopy (TEM) operating at $100 \mathrm{kV}$. Samples of about $30 \mu \mathrm{l}$ of $\mathrm{nC}_{60}$ were disposed onto $300 \mu \mathrm{m}$ mesh TEM grids (SPI) coated with Formvar. Analysis was performed after $24 \mathrm{~h}$ in order to allow sample evaporation (Lyon et al., 2006). The particle sizes and polydispersity indexes of the formulations were determined by dynamic light scattering (Zetasizer Nano series, ZEN 3600 - Malvern Instruments) in terms of intensity of particles after dilution in water (100 folds).

\subsection{Nanosilver suspension, preparation and characterization}

A colloidal suspension of $1 \% \mathrm{w} / \mathrm{v}$ nanoparticulate silver was provided by Nanotek S.A., which manufacture the product under the brand name nanArgen ${ }^{\circledR}$. To synthesize the nano-sized $\mathrm{Ag}$ colloid, silver nitrate as a source of silver was dissolved in Milli pore water to a concentration of $0.20 \mathrm{M}$ and mixed with an aqueous solution of $0.1 \mathrm{M}$ polyvinyl pyrrolidone (PVP) as the stabilizing agent. Next soluble starch in a $0.02 \mathrm{M}$ solution was added as a reducing agent. The reaction mixture was then placed in a pressurized reactor and held at $130{ }^{\circ} \mathrm{C}$ for $30 \mathrm{~min}$. All reagents and solvents were used as received without further purification. Scanning electron microscopy (SEM) and dynamic light scattering were employed in order to characterize the nanoparticulate silver suspension.

\subsection{Polychaetes sampling, maintenance and exposure design}

A total of 105 species of $L$. acuta adult, weighing in average $250 \mathrm{mg}$ were collected in a salt marsh ("Saco do Justino") around Rio Grande city (Southern, Brazil $-32^{\circ} \mathrm{S}, 52^{\circ} \mathrm{W}$ ), a site previously 
characterized as an unpolluted reference site (Geracitano et al., 2004; Ferreira-Cravo et al., 2007). After sampling, worms were immediately transported to laboratory where they were transferred to glass tubes with $5 \mathrm{~mL}$ of autoclaved estuarine water. The glass tubes were capped with cotton in order to avoid bacterial contamination from the environment. Abiotic parameters (salinity, $\mathrm{pH}$ and oxygen concentration) were measured in autoclaved estuarine water. Saline water employed in the assays presented the following parameters: $\mathrm{pH}=8.62 \pm 0.04$; salinity $=13.33 \pm 0.29$; oxygen concentration $=4.8 \pm 0.07 \mathrm{mg} / \mathrm{L}$. Field studies with $L$. acuta have reported similar $\mathrm{pH}$ values $(8.31 \pm 0.01)$ and similar or even more higher salinities (from $10.20 \pm 0.20$ to $35.53 \pm 0.33$ ) (FerreiraCravo et al., 2007).

Concentrations chosen in the assays were $0.01 ; 0.10$ or $1.00 \mathrm{mg} / \mathrm{L}$ of $\mathrm{nC}_{60}$ or $\mathrm{nAg}$ plus a control with saline water. Fullerene concentrations were selected taking into account a previous study from our group, where employing the above concentrations it was observed a growth reduction in bacteria living in the mucus secretion of common carp (Letts et al., 2011). The same concentrations were selected for $\mathrm{nAg}$ in order to favor the comparison between the two NM. Nanomaterial suspensions were all filtered on $0.22 \mu \mathrm{m}$ filters before exposure to avoid bacterial contamination. Five polychaetes per concentrations were assayed. Organisms were exposed in the glass tubes containing $5 \mathrm{~mL}$ of saline water to which it was spiked with different concentrations of $\mathrm{nC}_{60}$ or $\mathrm{nAg}$ or with saline water only (control group) during $24 \mathrm{~h}$ under darkness at $20^{\circ} \mathrm{C}$. Previous studies have evaluated bactericidal properties of NM as fullerene after spiking the nutritive culture media (Lyon et al., 2006; Letts et al., 2011), similar to what performed in present study adding NM aliquots to autoclaved estuarine water, sampled in a non-impacted salt marsh.

\subsection{Bacterial community isolation from L. acuta and counting of colony forming units}

After $24 \mathrm{~h}$, bacterial communities living at the mucus of three worms at each concentration of $\mathrm{nC}_{60}$ or $\mathrm{nAg}$ plus the control group were isolated with disposable loops of $10 \mu \mathrm{L}$ (passed twice over the animal surface) and transferred to Eppendorfs containing $280 \mu \mathrm{L}$ of autoclaved distilled water. The drop-plate method was done according to Herigstad et al. (2001). Samples were diluted between 10 and 10,000 times and inoculated in Petri dishes containing tryptic soy Agar (Hi-Media).

Each treatment dilution had four $10 \mu \mathrm{L}$ drops replicates. A control test was carried out as well, consisting of a pair of plates inoculated with autoclaved distilled water and sterile autoclaved estuarine water $(280 \mu \mathrm{L}$ of autoclaved distilled water plus $20 \mu \mathrm{L}$ of autoclaved estuarine water). The plates were incubated for approximately $20 \mathrm{~h}$ at $20^{\circ} \mathrm{C}$ in the dark. After this time, the colony forming units (CFU) obtained from samples of the mucus of worms were counted.

\subsection{Molecular identification of bacteria living at the mucus secretion of L. acuta}

DNA was extracted from $1 \mathrm{~mL}$ of isolated bacteria cultures using the Wizard Genomic DNA Purification kit (Promega, Madison, WI) according to the supplier's instructions. Extraction products were visualized on $1 \%$ agarose gel with GelRed (Biotium). Primers of $16 \mathrm{~S}$ segment (forward 5'-CCTACGGGAGGCAGCAG-3' and reverse 5'GACTACCAGGGTATCTAATC-3') were designed as described previously (Ritchie et al., 2008). DNA samples were amplified through polymerase chain reaction (PCR), which was performed according to Ritchie et al. (2008), except for the primer annealing temperature, which was optimized for $58{ }^{\circ} \mathrm{C}$. PCR products (approximately 460-bp long) were analyzed on GelRed-stained 1\% agarose gel, with Low DNA Mass Ladder (Invitrogen) as molecular weight marker, and then purified using the enzymes exonuclease I and shrimp alkaline phosphatase. Purified PCR products were sequenced in both directions using a MegaBACE 1000 automated sequencer. The resulting chromatograms were analyzed, and DNA sequences were blasted using GenBank National Center for Biotechnology Information-BLAST searches.

\subsection{Homogenization of the bacterial samples}

After the counting, Petri plates were incubated during two weeks and after they were scrapped and the bacteria material transferred to Eppendorfs and weighed, in order to estimate their biomass. Bacteria samples were diluted 1:10 in phosphate-buffered saline (PBS) (137 mM NaCl and $3 \mathrm{mM}$ of sodium phosphate, with $\mathrm{pH}$ adjusted to 7.4) and then frozen in liquid nitrogen and then thawed, three times, in order to promote their homogenization. After, samples were centrifuged at $9000 \times g$ for $40 \mathrm{~min}$ at $4{ }^{\circ} \mathrm{C}$. The supernatant was used for biochemical analysis. Total protein content was measured using a commercial diagnostic kit (Doles, Brazil), based on the Biuret method and read in an ELISA plate reader (Biotek ELx 800) at $550 \mathrm{~nm}$.

\subsection{Homogenization of $L$. acuta samples}

After exposure, worms were sacrificed putting them at $-80{ }^{\circ} \mathrm{C}$ and then dissected and subdivided in three regions: anterior region (A: first 20 settiger segments), middle region (M: next 20 settiger segments) and posterior region ( $\mathrm{P}$ : the rest of the body, approximately 57 segments) (Rosa et al., 2005). Samples were weighed and homogenized $(1: 3)$ in cold $\left(4^{\circ} \mathrm{C}\right)$ buffer solution containing $20 \mathrm{mM}$ Tris-Base, $1 \mathrm{mM}$ EDTA, $50 \mathrm{mM}$ sacarose, $150 \mathrm{mM} \mathrm{KCl}$ and $0.1 \mathrm{mM}$ phenylmethylsulfonyl fluoride (PMSF; Sigma), with $\mathrm{pH}$ adjusted to 7.6 (Geracitano et al., 2004). Homogenates were then centrifuged at $9000 \times g$ during $45 \mathrm{~min}$ at $4{ }^{\circ} \mathrm{C}$ and the supernatants kept. Pools of A, M or P sections were formed to make one sample. Total protein content of the supernatant was measured in the same way as for bacteria samples.

\subsection{Antioxidant and oxidative damage measurements}

Total antioxidant competence against peroxyl radicals, levels of by-products from lipid peroxidation (TBARS assay) and activity of glutathione-S-transferase (GST) were performed according to previous studies (Oakes and Van Der Kraak, 2003; Amado et al., 2009; Díaz-Jaramillo et al., 2011).

GST activity was estimated by the conjugation of $1 \mathrm{mM}$ glutathione (Sigma) with $1 \mathrm{mM}$ of 1-chloro-2, 4-dinitro-benzene (CDNB; Sigma), which it is measured as absorbance increments at $340 \mathrm{~nm}$ (Habig and Jakoby, 1981).

For total antioxidant capacity, peroxyl radicals were produced by thermal $\left(35^{\circ} \mathrm{C}\right)$ decomposition of $2,2^{\prime}$-azobis 2 methylpropionamidine dihydrochloride (ABAP; $4 \mathrm{mM}$; Aldrich). Readings were carried out in a fluorescence microplate reader (Victor 2, Perkin Elmer), in a medium containing $30 \mathrm{mM}$ HEPES ( $\mathrm{pH} 7.2$ ), $200 \mathrm{mM} \mathrm{KCl}, 1 \mathrm{mM} \mathrm{MgCl}$, and 2,7'-diclorodihidrofluorescein diacetate $\left(\mathrm{H}_{2} \mathrm{DCF}-\mathrm{DA} ; 40 \mu \mathrm{M}\right)$. Total fluorescence generation (excitation: $485 \mathrm{~nm}$, emission: $530 \mathrm{~nm}$ ) was calculated by integrating the fluorescence units (FU) along the measurement time (35 min), after adjusting FU data to a second order polynomial function. The relative difference between ROS area with and without ABAP was considered a measure of antioxidant competence, with high area difference meaning low antioxidant capacity, since high 
fluorescence levels were obtaining after adding ABAP, meaning low competence to neutralize peroxyl radicals (Amado et al., 2009).

Levels of lipid peroxidation were determined through the reaction of malondialdehyde (MDA), a degradation product of lipid peroxidation, with thiobarbituric acid (TBA) under conditions of high temperature and acidity, producing a chromogen which was quantified by fluorometry (excitation: $520 \mathrm{~nm}$, emission: $580 \mathrm{~nm}$ ). Aliquots of worm homogenates were incubated at $95{ }^{\circ} \mathrm{C}$ during 30 min with $35 \mu \mathrm{M}$ of butylated hydroxytoluene, $8.1 \%$ sodium dodecyl sulfate, $20 \%$ acetic acid and $0.8 \%$ TBA. After cooling to room temperature, n-butanol was added, centrifuged at $3000 \times g$ for $10 \mathrm{~min}$ at $15^{\circ} \mathrm{C}$. Tetramethoxypropane (ACROS Organics) was used as standard. Fluorescence was read at room temperature using a plate reader fluorimeter (Victor 2, Perkin Elmer).

\subsection{Measurement of silver accumulation in different body regions of L. acuta}

Anterior, middle and posterior regions of $L$. acuta were dissected as stated in Section 2.7. Samples were lyophilized and then the samples were digested by using an acidic oxidant mixture containing $\mathrm{HNO}_{3}$ and $\mathrm{H}_{2} \mathrm{O}_{2}$. Firstly, the weighted solid samples were added of $500 \mu \mathrm{L}$ of concentrated $\mathrm{HNO}_{3}$ and heated at $90^{\circ} \mathrm{C}$ for $6 \mathrm{~h}$ (without boiling). After cooling, $5 \mathrm{~mL}$ of concentrated $\mathrm{HNO}_{3}$ was added to the samples and refluxed once again for $30 \mathrm{~min}\left(95^{\circ} \mathrm{C}\right)$. After, $50 \mu \mathrm{L}$ of $\mathrm{H}_{2} \mathrm{O}_{2} 30 \%$ was included in the digestion tubes and heated for $1 \mathrm{~h}$, cooled down and diluted to $1 \mathrm{~mL}$ with ultrapure water. The recovery for $\mathrm{Ag}$ using this extraction procedure was 95.05\% $(n=5)$ for an $\mathrm{Ag}$ concentration of $25 \mu \mathrm{g} / \mathrm{L}$ added to samples submitted to the digestion procedure. Recovery experiments were carried out by using a NIST reference standard of Ag (SRM 3151). Determination of $\mathrm{Ag}$ in the digested samples was made by using an external calibration curve ranging from 5.0 to $30.0 \mu \mathrm{g} / \mathrm{L}$ of Ag. Here, a stock solution of $A g 1.0 \mathrm{~g} / \mathrm{L}$ was diluted to $10 \mathrm{mg} / \mathrm{L}$, so that it was used as a working intermediate solution for preparing the calibration curve. Measurements were performed in a AnalytikjenaZEEnit 600 atomic absorption spectrometer (Analytikjena, Germany), equipped with an auto-sampler MPE 60.

\subsection{Statistical analysis}

Statistical differences between various parameters were tested through analysis of variance (ANOVA), followed by Newman-Keuls test $(\alpha=0.05)$. Assumptions of normality and variance homogeneity were previously checked and logarithmic transformations applied if necessary (Zar, 1984).

\section{Results}

Fig. 1 shows the TEM images for $\mathrm{nC}_{60}$ (a) and $\mathrm{nAg}$ (b), after the analysis of three independent samples. As observed in Fig. 1a, aqueous suspensions of fullerene showed rather regular spherical particles gathered in aggregates in form of chains. Some of the registered nAg images (Fig. 1b) showed spherical nanoparticles of an average size ranging between 20 and $25 \mathrm{~nm}$. Further size analysis using dynamic light scattering indicated the existence of polydispersed particles population, with polydispersity indexes of 0.454 and 0.712 for $\mathrm{nC}_{60}$ and $\mathrm{nAg}$, respectively. The formulation $\mathrm{nC}_{60}$ presented two populations, with particles of 149.5 and $2750 \mathrm{~nm}$. $\mathrm{nAg}$ formulation presented particles of 205.6 and $33.51 \mathrm{~nm}$.

The number of bacterial CFU obtained from samples of the mucus of the worms exposed to $\mathrm{nC}_{60}$ was lower for the concentration of $0.01 \mathrm{mg} / \mathrm{L}$ when compared with the other concentrations and the control group $(p<0.05)$ (Fig. 2a). No statistically significant

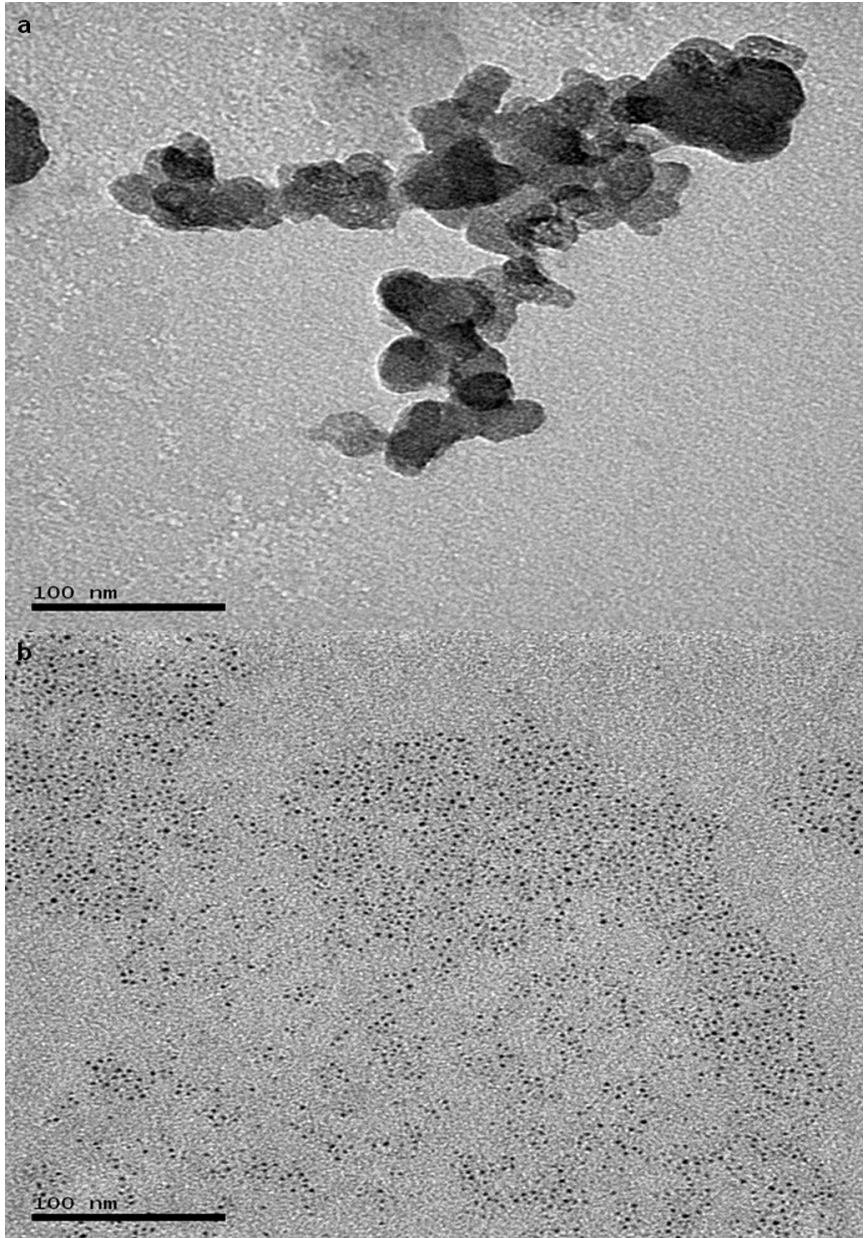

Fig. 1. Transmission electron microscopy image of the aqueous fullerene $\left(\mathrm{nC}_{60}\right)(\mathrm{a})$ and nanosilver (nAg) (b) suspensions employed in the bioassays.

differences $(p>0.05)$ of bacteria biomass weight were found for fullerene treatments (Fig. 2b). CFU data obtained from samples of the mucus of $\mathrm{nAg}$ exposed worms were in accordance to biomass weight, as they decreased for the highest concentration $(1.0 \mathrm{mg} / \mathrm{L})$ in relation to the other concentrations and control $(p<0.05)$ (Fig. 2c and d).

Total DNA was extracted from the eight isolates obtained and the $16 \mathrm{~S}$ rDNA sequences were partially determined. One isolate was identified as Shewanella, and seven isolates were identified as belonging to Vibrio genera (Table 1 ).

Antioxidant capacity against peroxyl radicals in homogenates of bacteria exposed to $\mathrm{nC}_{60}$ was lowest (higher relative area) in the concentration of $0.1 \mathrm{mg} / \mathrm{L}$ when compared to the control $(p<0.05)$ (Fig. 3a). Treatment with nAg did not alter $(p>0.05)$ the antioxidant competence against peroxyl radicals (Fig. 3b).

Although several attempts with different extracts volumes were tested, no GST activity was detected in the majority of the bacteria samples. In a bacteria control group only one sample from five differed from a blank and in bacteria samples from NM-exposed worms were also few. However a trend to higher GST activity was observed in bacteria samples coming from NM-exposed worms, particularly $\mathrm{nAg}$. As examples, a bacteria control sample presented a GST activity of $0.017 \mathrm{nmol} / \mathrm{min} / \mathrm{mg}$ of proteins, whereas samples obtained from CFU isolated from mucus of worms exposed to $\mathrm{nAg}$ were $0.27 \pm 0.04 \mathrm{nmol} / \mathrm{min} / \mathrm{mg}$ of proteins (mean $\pm 1 \mathrm{SD} ; n=3$ ) at the concentration of $0.01 \mathrm{mg} / \mathrm{L} ; 0.086 \mathrm{nmol} / \mathrm{min} / \mathrm{mg}$ of proteins at 



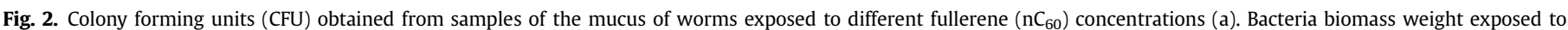

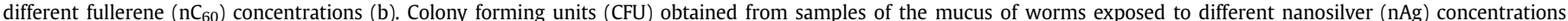

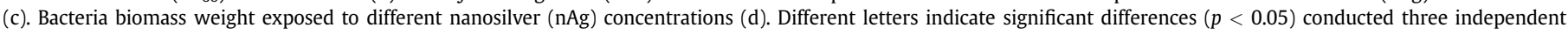
experiments $(n=9)$.

the concentration of $0.1 \mathrm{mg} / \mathrm{L}(n=1)$ and $2.6 \pm 1.58 \mathrm{nmol} / \mathrm{min} / \mathrm{mg}$ of proteins (mean $\pm 1 \mathrm{SD} ; n=3$ ) at the concentration of $1 \mathrm{mg} / \mathrm{L}$. Homogenates of bacteria exposed to $\mathrm{nC}_{60}$ and $\mathrm{nAg}$ showed no significant differences in levels of lipid peroxidation $(p>0.05$; data not shown).

Antioxidant capacity was different along the body regions of $L$. acuta exposed to $\mathrm{nC}_{60}$. As showed in Fig. 4a, the anterior region presented lower antioxidant capacity $(p<0.05)$ in worms exposed to $1.0 \mathrm{mg} / \mathrm{L}$, when compared to the control. The other body regions did not presented statistical differences $(p>0.05)$ between treatments (Fig. 4b and c). Worms exposed to $\mathrm{nAg}$ showed absence of effect in the anterior and middle region (Fig. $4 \mathrm{~d}$ and e), but presented lower antioxidant capacity (higher relative area) in the posterior region of those exposed to $1.0 \mathrm{mg} / \mathrm{L}$ when compared to the control ( $p<0.05$; Fig. 4f).

Levels of lipid peroxidation (TBARS) were reduced in the anterior region of worms exposed to the two highest concentrations $(0.1$ and $1.0 \mathrm{mg} / \mathrm{L})$ of $\mathrm{nC}_{60}(p<0.05)$ (Fig. 5a). In the middle region (Fig. 5b), no statistical differences were observed between all treatments $(p>0.05)$. Finally, in the posterior body region (Fig. 5c), only worms exposed to the highest $\mathrm{nC}_{60}$ concentration $(1.0 \mathrm{mg} / \mathrm{L})$ showed augmented TBARS concentration when compared with the

Table 1

Molecular identification of bacteria living at the surface of the estuarine polychaete Laeonereis acuta.

\begin{tabular}{lll}
\hline Isolated colony & Identity & GenBank accession number \\
\hline C.1 & Vibrio sp. & JN835409 \\
C. 2 & Vibrio sp. & JN835410 \\
C.3 & Shewanella sp. & JN835411 \\
C.4 & Vibrio sp. & JN835412 \\
C.5 & Vibrio sp. & JN835413 \\
C.6 & Vibrio sp. & JN835414 \\
C.7 & Vibrio sp. & JN835415 \\
C.8 & Vibrio sp. & JN835416 \\
\hline
\end{tabular}

control group ( $p<0.05$ ). Worms exposed to nAg showed no significant differences in TBARS content ( $p>0.05$; data not shown).

Activity of GST in worms exposed to $\mathrm{nC}_{60}$ revealed: (1) no differences in the anterior region ( $p>0.05$; Fig. 6a); (2) to be decreased $(p<0.05)$ in the middle region of worms exposed to $1.0 \mathrm{mg} / \mathrm{L}$ (Fig. $6 \mathrm{~b}$ ); and (3) to be increased $(p<0.05)$ in the posterior region of worms exposed to $0.1 \mathrm{mg} / \mathrm{L}$ of $\mathrm{nC}_{60}$ (Fig. 6c). No effect of $\mathrm{nAg}(p>0.05)$ was observed (data not shown).

In terms of silver accumulation, only in the posterior region (that accounts for almost the whole worm) were obtained readings different from the blank. The posterior regions of worms exposed to the lowest $\mathrm{nAg}$ concentration $(0.01 \mathrm{mg} / \mathrm{L})$ showed the highest silver accumulation $(5.58 \pm 1.23 \mu \mathrm{g} / \mathrm{g})$ when compared with worms exposed to $0.1 \mathrm{mg} / \mathrm{L}(1.24 \pm 0.62 \mu \mathrm{g} / \mathrm{g})$ or $1.0 \mathrm{mg} / \mathrm{L}(0.48 \pm 0.35 \mu \mathrm{g} / \mathrm{g})$ $(p<0.05)$.

\section{Discussion}

Mucus from marine invertebrates may play different functions, although the information about this issue is still scarce (Stabili et al., 2011). Mucus from the polychaeta L. acuta presents high density of bacteria communities (Moraes et al., 2006). In present study it were isolated eight colonies living at the mucus from $L$. acuta, where seven belong to Vibrio genera and the other was identified as Shewanella (Table 1). The genus Vibrio sp. are Gram-negative bacteria, pathogenic to vertebrate and invertebrate animals (Kim and Bang, 2008), whereas the Shewanella genus comprises a group of Gram-negative bacteria that have been isolated from marine environments, sediments and marine organisms like abalone Haliotis discus hannai (Kim et al., 2007). Authors like Stabili et al. (2011) have observed a lysozyme-like activity in the mucus of the polychaeta S. spallanzanii to different Vibrio genera, suggesting that the community composition and bacteria density are controlled by the worms. Fang et al. (2007) observed that both Gram-negative and 

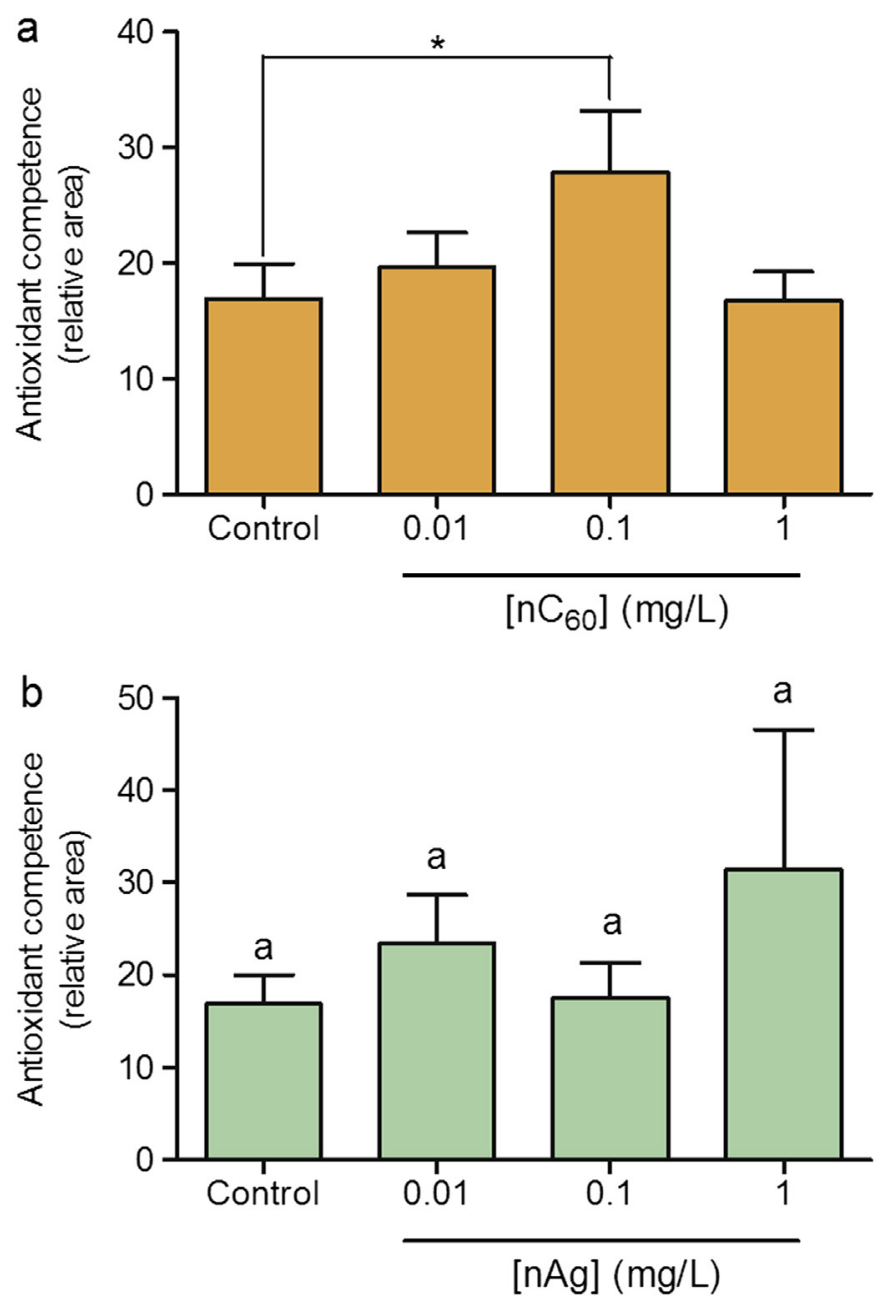

Fig. 3. Total antioxidant capacity against peroxyl radicals (relative area) of the bacterial samples exposed to different fullerene $\left(\mathrm{nC}_{60}\right)(\mathrm{a})$ and nanosilver $(\mathrm{nAg})(\mathrm{b})$ concentrations. Asterisk $\left({ }^{*}\right)$ indicates significant differences $(p<0.05)$ between treatments connected by solid lines. Number of analyzed samples were 3 for each treatment being conducted three independent experiments $(n=9)$.

Gram-positive bacteria can change its lipid composition and membrane phase behavior when exposed to $\mathrm{nC}_{60}$.

The sediment is a sink for many contaminants in water ecosystems and probably this is also true for aggregated nanoparticles. In these instances, it may be more appropriate to study the effects of the NM on benthic organisms rather than on water-column species. From this point of view, the invertebrate $L$. acuta seems to be an appropriate model to analyze the potential risks elicited by NM on estuarine organisms.

Fullerene $\left(\mathrm{nC}_{60}\right)$ upon contact with water can form negatively charged nanoscaled colloids, which are stable over time (Fortner et al., 2005). The conditions that lead to ROS production by $\mathrm{nC}_{60}$ in water and the reactive species formed are less well understood. According to Lee et al. (2008), differences in the aggregation state of $\mathrm{nC}_{60}$ as well as functionalization of then $\mathrm{C}_{60}$ contained within these aggregates may affect the ability for ROS production. In the present study bacteria CFU obtained from samples of the mucus of worms exposed to $\mathrm{nC}_{60}$ was lowered at the concentration of $0.01 \mathrm{mg} / \mathrm{L}$ when compared with the other concentrations and the control group (Fig. 2a). This result can be explained by the degree and kinetics of aggregation and the size range of the aggregates that depends on characteristics of the particle and its concentration, as well of the characteristics of the environmental system (Farré et al.,
2011). Nel et al. (2006) showed that lower NM concentrations should have smaller aggregates that could affect bacterial communities, as we observed. According to Tiede et al. (2009), it is possible to observe higher toxicity at lower test concentrations because the extent of aggregation at these concentrations can be likely reduced, leaving free particles in un-aggregated form.

The antioxidant capacity against peroxyl radicals in homogenates of bacteria exposed to $\mathrm{nC}_{60}$ was lower (higher relative area) for the concentration of $0.1 \mathrm{mg} / \mathrm{L}$ when compared to the control (Fig. 3a), indicating that even in darkness (where $\mathrm{nC}_{60}$ is not expected to be photo-excited) this NM was able to reduce the antioxidant competence of the bacteria communities living at the mucus secretion of $L$. acuta. The content of organic matter (OM) in estuarine environments should be considered as a factor that influences fullerene toxicity. Xie et al. (2008) reported that changes in $\mathrm{nC}_{60}$ size and morphology correlated with $\mathrm{OM}$ content. The presence of organic matter (OM) in ecotoxicity tests is known to affect the bio-availability and toxicity of, especially, hydrophobic organic substances (Baun et al., 2008). Thus, it can be considered that $\mathrm{nC}_{60}$ may have caused alterations in the antioxidant capacity in the anterior region $L$. acuta, through of ROS, due to OM presence in the estuarine water and employed to perform the assays.

Enzymes of glutathione-S-transferase (GST) group play a key role in cellular detoxification, protecting cells against pollutants or toxicants by conjugating them to glutathione and other endogenous molecules. No GST activity was detected in most of bacteria communities. This result was similar to Moraes et al. (2006), since these authors were unable to detect GST activity in mucus sampled from $L$. acuta. However GST activity decreased in the middle and posterior region of worms exposed to $1.0 \mathrm{mg} / \mathrm{L}$ of $\mathrm{nC}_{60}$ (Fig. 6a) and increased in the posterior region of worms exposed to $0.1 \mathrm{mg} / \mathrm{L}$ of $\mathrm{nC}_{60}$ (Fig. $6 \mathrm{~b}$ and c) when compared with other treatments. These results suggest a dualistic effect of fullerene since, depending of the region of the worm, decreased or increased GST activity, thus modulating the detoxification capacity of each body regions in opposite ways.

It is difficult to predict whether fullerene will act as an anti- or pro-oxidant in vivo (Zhu et al., 2006). In this study we observed both conditions, since lipid peroxides content was reduced in the anterior region of worms exposed to the two highest concentrations $(0.1$ and $1.0 \mathrm{mg} / \mathrm{L})$ of $\mathrm{nC}_{60}$, indicating an antioxidant behavior (Fig. 5a). Díaz-Jaramillo et al. (2011) found absence of toxic responses mediated by oxidative stress in estuarine worms Perinereis gualpensis exposed to fullerene mixed in sediments. In fact these authors observed that under this exposure condition, fullerene elicited an antioxidant response triggering higher total antioxidant competence against peroxyl radicals in exposed worms.

Contrary to the antioxidant effect observed in the anterior region, a pro-oxidant behavior of $\mathrm{nC}_{60}$ was registered in the posterior region of worms exposed to the highest $\mathrm{nC}_{60}$ concentration $(1.0 \mathrm{mg} / \mathrm{L})$ that showed augmented TBARS concentration when compared with the control group (Fig. 5c). A previous study of Ferreira-Cravo et al. (2007) reported that $L$. acuta presents a body gradient of ROS concentration, being lowest at the anterior region and highest at the posterior region. It is hypothesized that $\mathrm{nC}_{60}$ internalized in the posterior region, with high ROS concentration should react with these chemical species, generating more reactive ones that should promote lipid peroxidation. The pro-oxidant effect of $\mathrm{nC}_{60}$ promoting lipid peroxidation has been previously reported in several other aquatic species (Zhu et al., 2008; Shinohara et al., 2009; Ribas Ferreira et al., 2012; Socoowski Britto et al., 2012).

Slow nanosilver dissolution to form silver ions is the most widely accepted mechanism described in the literature to explain nanosilver effects on biota. For example, Hwang et al. (2008) performed a study of stress-specific bioluminescent bacteria, based on 
Anterior region

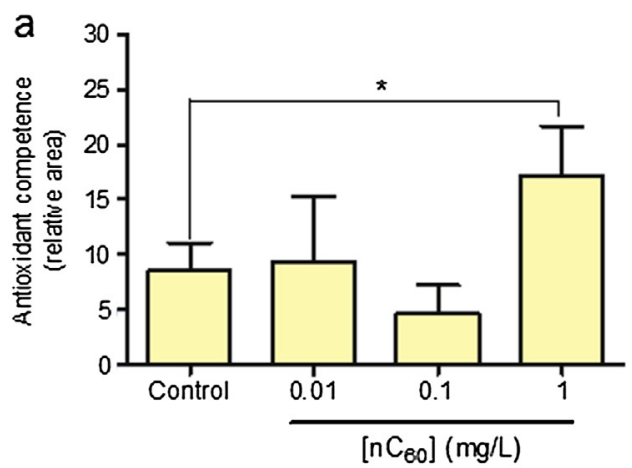

Middle region

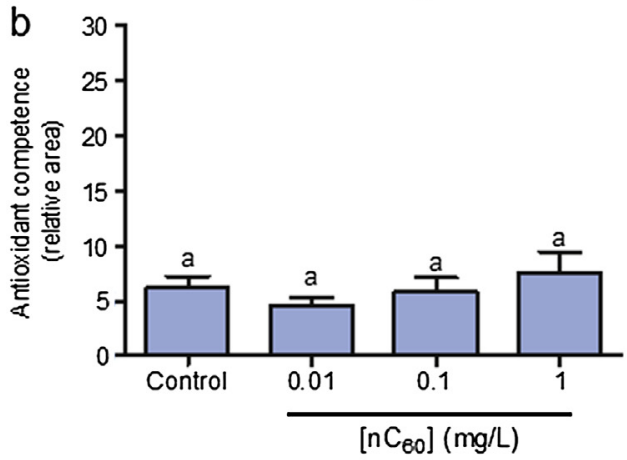

Posterior region

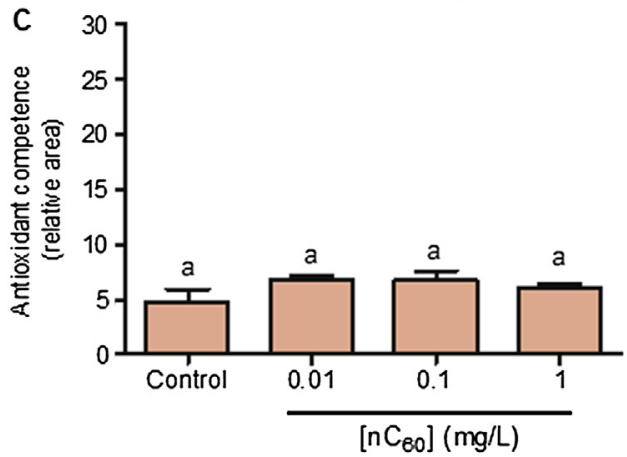

Anterior region

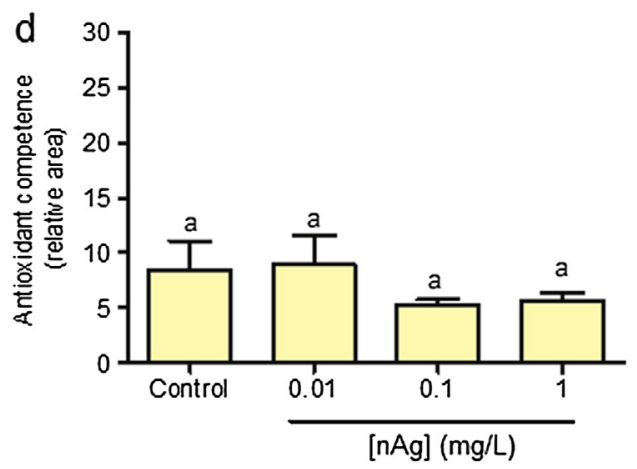

Middle region

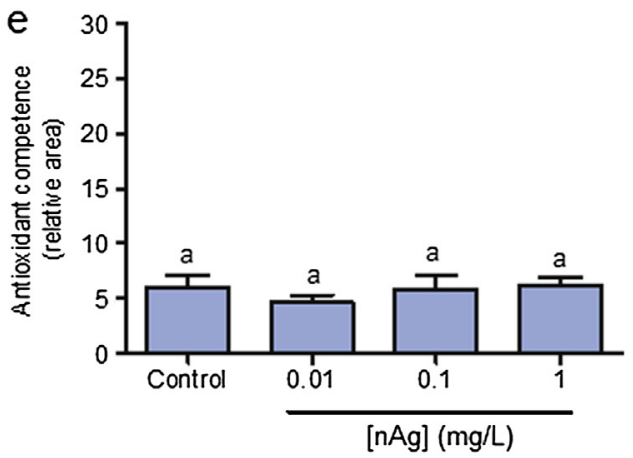

Posterior region

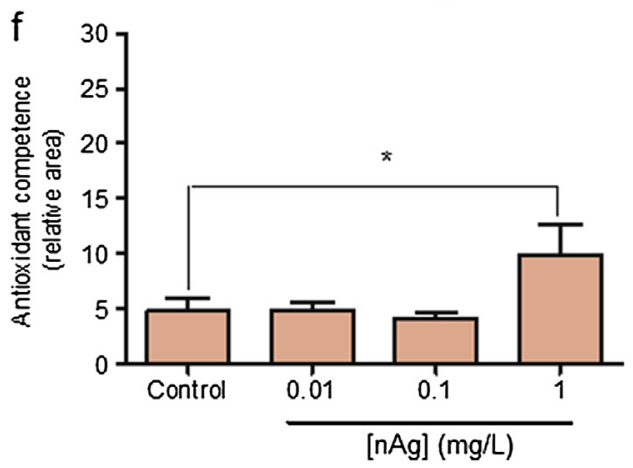

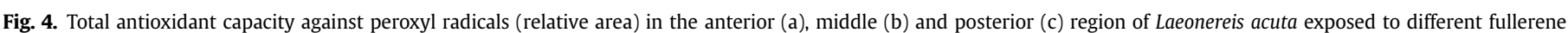

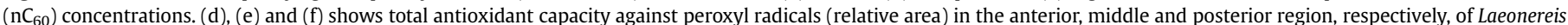

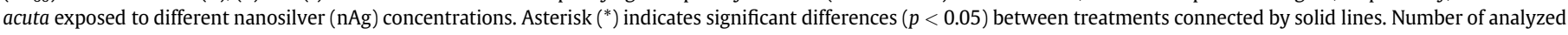
samples were 5 for each treatment being conducted three independent experiments $(n=15)$.

a synergistic toxic effect of the silver nanoparticles and the silver ions that they produce. The ions move into the cells and lead to ROS production. Because of the membrane damage caused by the nanoparticles, the cells cannot effectively extrude the silver ions and limit their effect. Based on the greater tendency of silver ions to strongly interact with thiol groups of vital enzymes and phosphorus-containing bases (Hatchett and White, 1996) and on the presence of silver nanoparticles inside the cells (Morones et al., 2005), it is likely that further damage could be caused by interactions with compounds such as DNA.

As mentioned previously, environmental conditions such as $\mathrm{pH}$, ionic strength, presence of complexing agents, and natural organic matter affect the toxicity of nAg (Marambio-Jones and Hoek, 2010). The high salts concentration promote nanoparticle aggregation (Marambio-Jones and Hoek, 2010), an important fact to consider when evaluating NM risks in estuarine environments. In our study, some evidence of $\mathrm{nAg}$ being agglomerated at the micrometric scale was obtained (laser diffractometry measurements), a result expected taking into account the high ionic strength of saline water. This in fact was also supported by data of silver accumulation in worms, since an inverse relationship was observed between silver accumulation in posterior region with the exposure concentration, meaning lower bio-availability at higher concentrations. However the higher concentration of $\mathrm{nAg}(1.0 \mathrm{mg} / \mathrm{L})$ decreased the bacterial $\mathrm{CFU}$ and also the weight of bacterial communities living at the surface of $L$. acuta (Fig. 2c and d). This result can be due to bactericidal or bacteriostatic effect on the bacterial communities living in estuarine organisms like $L$. acuta even when the exposure conditions (high concentration of $\mathrm{nAg}$ in saline water) should impose the presence of silver particles in the micrometric range (Navarro et al., 2008). However, previous studies, using the same concentration, have reported bacteria growth inhibition by $\mathrm{nAg}$ (Choi et al., 2008). 


\section{Anterior region}

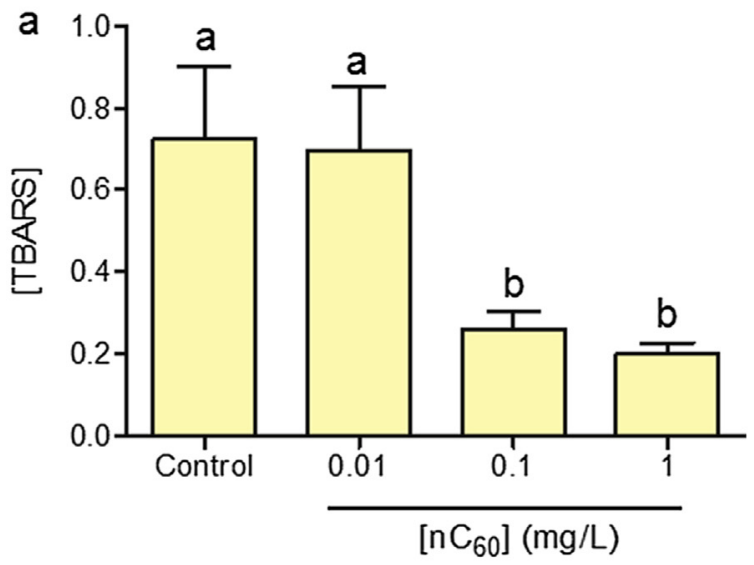

Middle region

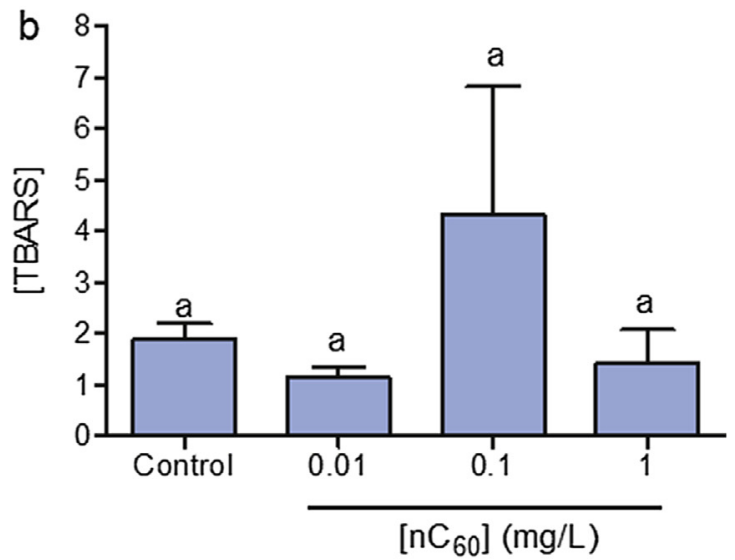

Posterior region



Fig. 5. Concentration of thiobarbituric acid reactive substances (TBARS; nmol/mg of proteins) in anterior (a), middle (b) and posterior (c) region exposed to different fullerene $\left(\mathrm{nC}_{60}\right)$ concentrations. Asterisk $\left.{ }^{*}\right)$ indicates significant differences $(p<0.05)$ between treatments connected by solid lines. Number of analyzed samples were 5 for each treatment being conducted three independent experiments $(n=15)$.

Although knowledge about toxicity mechanism of nAg in invertebrates is limited, some studies have also shown how the type of capping of the $\mathrm{nAg}$, ionic strength and concentration of organic carbon of the biological media are crucial for predicting and understanding toxicity (Fabrega et al., 2011).
Anterior region

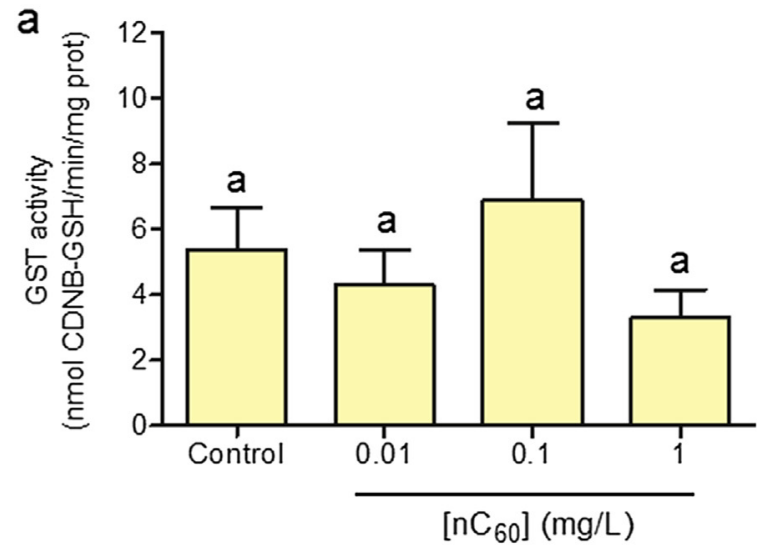

Middle region

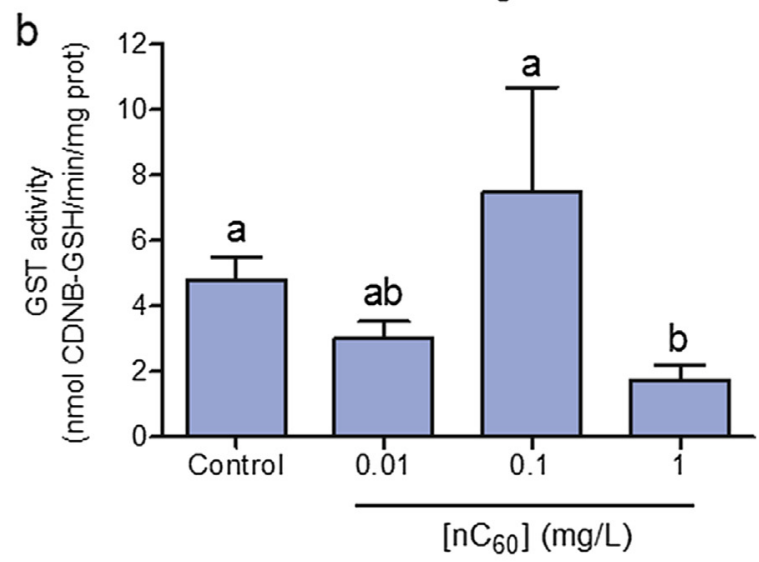

Posterior region

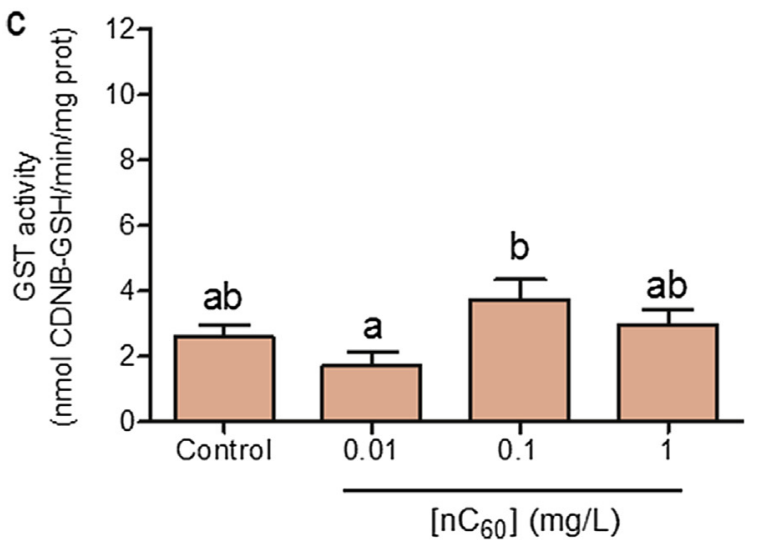

Fig. 6. Activity of glutathione-S-transferase (GST) (nmol CDNB-GSh/min/mg prot) in anterior (a) middle (b) and posterior region (c) exposed to different fullerene $\left(\mathrm{nC}_{60}\right)$ concentrations. Number of analyzed samples were 5 for each treatment, being conducted three independent experiments $(n=15)$. Different letters indicate significant differences $(p<0.05)$ between means of different treatments. Number of analyzed samples were 5 for each treatment, being conducted three independent experiments $(n=15)$.

\section{Conclusion}

The two $\mathrm{NM}, \mathrm{nC}_{60}$ and $\mathrm{nAg}$, induced toxic effects in the polychaete $L$. acuta and in their associated bacteria communities still in a typical situation for a burrowing worm (darkness), where the 
fullerene is not photo-excited. Complex interactions between estuarine organisms and associated bacteria should be jeopardized by NM, with ecological consequences that need to be properly evaluated.

\section{Role of the funding source}

The research was supported by a grant from the Brazilian agency CNPq (Proc. $n^{\circ}$ 471459/2007-0) given to J.M. Monserrat. L. Machado de Carvalho, M. Reis Bogo and J. M. Monserrat are research fellows from Brazilian CNPq. The logistic and material support from the Instituto Nacional de Ciência e Tecnologia de Nanomateriais de Carbono (CNPq) was fundamental for the execution of present study. The work was supported by DECIT/SCTIE-MS through Conselho Nacional de Desenvolvimento Científico e Tecnológico $(\mathrm{CNPq})$, of the Fundação de Amparo à Pesquisa do Estado do Rio Grande do Sul (FAPERGS, Proc. 10/0036-5-PRONEX/Conv. 700545/ 2008) and by Nanotoxicology Network (MCTI/CNPq process number $552131 / 2011-3$ ).

\section{Acknowledgments}

Authors acknowledge the laboratory technicians working at the Instituto de Ciências Biológicas (ICB), FURG (MSc. Sandra Carvalho) and the Electronic Microscopy Center, at the Universidade Federal do Rio Grande do Sul (UFRGS). Authors also acknowledge the support of Dr. Silvia S. Guterres.

\section{References}

Amado, L.L., Garcia, M.L., Ramos, P.B., Freitas, R.F., Zafalon, B., Ferreira, J.L.R Yunes, J.S., Monserrat, J.M., 2009. A method to measure total antioxidant capacity against peroxyl radicals in aquatic organisms: application to evaluate microcystins toxicity. Science of the Total Environment 407, 2115-2123.

Andrievsky, G., Klochkov, V., Derevyanchenko, L., 2005. Is the $C_{60}$ fullerene molecule toxic? Fullerenes, Nanotubes, and Carbon Nanostructures 13, 363-376.

Azevedo Costa, C.L., Chaves, I.S., Ventura-Lima, J., Ribas Ferreira, J.L., Ferraz, L Machado de Carvalho, L., Monserrat, J.M., 2012. In vitro evaluation of coexposure of arsenium and an organic nanomaterial (fullerene, $C_{60}$ ) in zebrafish hepatocytes. Comparative Biochemistry and Physiology C 155, 206-212.

Baun, A., Hartmann, N.B., Grieger, K., Kusk, K.O., 2008. Ecotoxicity of engineered nanoparticles to aquatic invertebrates: a brief review and recommendations for future toxicity testing. Ecotoxicology 17, 387-395.

Bilberg, K., Døvingb, K.B., Beedholm, K., Baatrup, E., 2011. Silver nanoparticles disrupt olfaction in Crucian carp (Carassius carassius) and Eurasian perch (Perca fluviatilis). Aquatic Toxicology 104, 145-152.

Bradford, A., Handy, R.D., Readman, J.W., Atfield, A., Muhling, M., 2009. Impact of silver nanoparticle contamination on the genetic diversity of natural bacterial assemblages in estuarine sediments. Environmental Science and Technology 43 4530-4536.

Choi, O., Deng, K.K., Kim, N.J., Ross, L., Surampalli, R.Y., Hu, Z.Q., 2008. The inhibitory effects of silver nanoparticles, silver ions, and silver chloride colloids on microbial growth. Water Research 42, 3066-3074.

Díaz-Jaramillo, M., Ribas, J., da Rocha, A.M., Bay-Smith, E., Fillmann, G., Barra, R., Monserrat, J.M., 2011. Antioxidant responses in the polychaete Perinereis gualpensis (Nereididae) exposed to the carbon nanomaterial fullerene $\left(C_{60}\right)$. Chemistry and Ecology 27, 43-48.

Fabrega, J., Luoma, S.N., Tyler, C.R., Galloway, T.S., Lead, J.R., 2011. Silver nanoparticles: behaviour and effects in the aquatic environment. Environment International 37, 517-531.

Fang, J., Lyon, D.Y., Wiesner, M.R., Dong, J., Alvarez, P.J.J., 2007. Effect of a fullerene water suspension on bacterial phospholipids and membrane phase behavior. Environmental Science and Technology 41, 2636-2642.

Farré, M., Sanchís, J., Barceló, D., 2011. Analysis and assessment of the occurrence, the fate and the behavior of nanomaterials in the environment. Trends in Analytical Chemistry 30, 517-527.

Ferreira, J.L.R., Barros, D.M., Geracitano, L.A., Fillmann, G., Fossa, C.E., de Almeida, E.A., de Castro Prado, M., Almeida Neves, B.R. Brant Pinheiro, M.V. Monserrat, J.M., 2012. In vitro exposure to fullerene $C_{60}$ influences redox state and lipid peroxidation in brain and gills from Cyprinus carpio (Cyprinidae). Environmental Toxicology and Chemistry 31, 961-967.

Ferreira-Cravo, M., Reinhardt Piedras, F., Moraes, T.B., Ferreira, J.L.R., Salomão, D.P.F., Dornelles Machado, M., Geracitano, L.A., Monserrat, J.M., 2007. Antioxidant responses and reactive oxygen species generation in different body regions of the estuarine polychaeta Laeonereis acuta (Nereididae). Chemosphere 66, 13671374.

Fortner, J.D., Lyon, D.Y., Sayes, C.M., Boyd, Falkner, J.C., Hotze, E.M., Alemany, L.B., Tao, Y.J., Guo, W., Ausman, K.D., Colvin, V.L., Hughes, J.B., 2005. C 60 in water: nanocrystal formation and microbial response. Environmental Science and Technology 39, 4307-4316.

Geracitano, L.A., Bocchetti, R., Monserrat, J.M., Regoli, F., Bianchini, A., 2004. Oxidative stress responses in two populations of Laeonereis acuta (Polychaeta, Nereididae) after acute and chronic exposure to copper. Marine Environmental Research 58, 1-17.

Habig, N.H., Jakoby, W.B., 1981. Assays for differentiation of glutathione-S-transferase. Methods in Enzymology 77, 398-405.

Hatchett, D.W., White, H.S., 1996. Electrochemistry of sulfur adlayers on low-index faces of silver. The Journal of Physical Chemistry 100, 9854-9859.

Henry, T.B., Menn, F.M., Fleming, J.T., Wilgus, J., Compton, R.N., Sayler, G.S., 2007. Attributing effects of aqueous $\mathrm{C}_{60}$ nano-aggregates to tetrahydrofuran decomposition products in larval zebrafish by assessment of gene expression. Environmental Health Perspectives 115, 1059-1065.

Herigstad, B., Hamilton, M., Heersink, J., 2001. How to optimize the drop plate method for enumerating bacteria. Journal of Microbiological Methods 44, 121-129.

Hwang, E.T., Lee, J.H., Chae, Y.J., Kim, Y.S., Kim, B.C., Sang, B., Gu, M.B., 2008. Analysis of the toxic mode of action of silver nanoparticles using stress-specific bioluminescent bacteria. Small 4, 746-750.

Kamat, J.P., Devasagayam, T.P.A., Proyadarsini, K.I., Mohan, H., 2000. Reactive oxygen species mediated membrane damage induced by fullerene derivatives and its possible biological implications. Toxicology 155, 55-61.

Kahru, A., Dubourguier, H.-C., 2010. From ecotoxicology to nanoecotoxicology. Toxicology 269, 105-119.

Kim, D., Baik, K.S., Kim, M.S., Jung, B., Shin, T., Chung, G., Rhee, M.S., Seong, C.N., 2007. Shewanella haliotis sp. nov., isolated from the gut microflora of abalone, Haliotis discus hannai. International Journal of Systematic and Evolutionary Microbiology 57, 2926-2931.

Kim, M.N., Bang, H.J., 2008. Detection of marine pathogenic bacterial Vibrio species by multiplex polymerase chain reaction (PCR). Journal of Environmental Biology 29, 543-546.

Lee, J., Yamakoshi, Y., Hughes, J.B., Kim, J., 2008. Mechanism of $\mathrm{C}_{60}$ photoreactivity in water: fate of triplet state and radical anion and production of reactive oxygen species. Environmental Science and Technology 42, 3459-3464.

Letts, R.E., Pereira, T.C., Bogo, M.R., Monserrat, J.M., 2011. Biological responses of bacteria communities living at the mucus secretion of common carp (Cyprinus carpio) after exposure to the nanocompound fullerene $\left(\mathrm{C}_{60}\right)$. Archives of Environmental Contamination and Toxicology 61, 311-317.

Li, T., Albee, B., Alemayehu, M., Diaz, R., Ingham, L., Kamal, S., Rodriguez, M., Bishonoi, S.W., 2010. Comparative toxicity study of Ag, Au, and Ag-Au bimetallic nanoparticles on Daphnia magna. Analytical and Bioanalytical Chemistry 398, 689-700

Lyon, D.Y., Adams, L.K., Falkner, J.C., Alvarez, P.J.J., 2006. Antibacterial activity of fullerene water suspensions: effects of preparation method and particle size. Environmental Science and Technology 40, 4360-4366.

Lyon, D.Y., Alvarez, P.J.J., 2008. Fullerene water suspension $\left(\mathrm{nC}_{60}\right)$ exerts antibacterial effects via ROS-independent protein oxidation. Environmental Science and Technology 42, 8127-8132.

Lyon, D.Y., Brunet, L., Hinkal, G.W., Wiesner, M.R., Alvarez, P.J.J., 2008. Antibacterial activity of fullerene water suspensions $\left(\mathrm{nC}_{60}\right)$ is not due to ROS-mediated damage. Nano Letters 8, 1539-1543.

Marambio-Jones, C., Hoek, E.M.V., 2010. A review of the antibacterial effects of silver nanomaterials and potential implications for human health and the environment. Journal of Nanoparticles Research 12, 1531-1551.

Moraes, T.B., Ribas Ferreira, J.L., Rosa, C.E., Sandrini, J.Z., Votto, A.P., Trindade, G.S., Geracitano, L.A., Abreu, P.C., Monserrat, J.M., 2006. Antioxidant properties of the mucus secreted by Laeonereis acuta (Polychaeta, Nereididae): a defense against environmental pro-oxidants? Comparative Biochemistry and Physiology 142, 293-300.

Morones, J.R., Elechiguerra, J.L., Camacho, A., Holt, K., Kouri, J.B., Ramírez, J.T., Yacaman, M.J., 2005. The bactericidal effect of silver nanoparticles. Nanotechnology 16, 2346-2353.

Navarro, E., Baun, A., Behra, R., Hartmann, N.B., Filser, J., Ai-Jun, M., Quigg, A., Santschi, P.H., Sigg, L., 2008. Environmental behavior and ecotoxicity of engineered nanoparticles to algae, plants, and fungi. Ecotoxicology 17, 372-386.

Nel, A., Xia, T., Mädler, L., Li, N., 2006. Toxic potential of materials at the nanolevel. Science 311, 622-627.

Oakes, K.D., Van Der Kraak, G.J., 2003. Utility of the TBARS assay in detecting oxidative stress in white sucker (Catostomus commersoni) populations exposed to pulp mill effluent. Aquatic Toxicology 63, 447-/463.

Oberdörster, E., 2004. Manufactured nanomaterials (fullerenes, $C_{60}$ ) induce oxidative stress in brain of juvenile largemouth bass. Environmental Health Perspectives 112, 1058-1062.

Oberholster, P.J., Musee, N., Botha, A.-M., Cheluled, P.K., Fockee, W.W., Ashton, P.J., 2011. Assessment of the effect of nanomaterials on sediment-dwelling invertebrate Chironomus tentans larvae. Ecotoxicology and Environmental Safety 74 416-423.

Raes, M., Vanreusel, A., 2006. Microhabitat type determines the composition of nematode communities associated with sediment-clogged cold-water coral framework in the Porcupine Seabight (NE Atlantic). Deep-Sea Research 53, $1880-1894$ 
Ritchie, L.E., Steiner, J.M., Suchodolski, J.S., 2008. Assessment of microbial diversity along the feline intestinal tract using16S rRNA gene analysis. Microbiological Ecology 66, 590-598.

Rosa, C.E., Iurman, M.G., Abreu, P.C., Geracitano, L.A., Monserrat, J.M., 2005. Antioxidant mechanisms of the nereidid Laeonereis acuta (Annelida: Polychaeta) to cope with environmental hydrogen peroxide. Physiological and Biochemical Zoology 78, 641-649.

Shinohara, N., Matsumoto, T., Gamo, M., Miyauchi, A., Endo, S., Yonezawa, Y., Nakanishi, J., 2009. Is lipid peroxidation induced by the aqueous suspension of fullerene $\mathrm{C}_{60}$ nanoparticles in the brains of Cyprinus carpio? Environmental Science and Technology 43, 948-953.

Socoowski Britto, R., Longaray Garcia, M., Martins da Rocha, A., Artigas Flores, J. Brant Pinheiro, M., Monserrat, J.M., Ribas Ferreira, J.L., 2012. Effects of carbon nanomaterials fullerene $\mathrm{C}_{60}$ and fullerol $\mathrm{C}_{60}(\mathrm{OH})_{18-22}$ on gills of fish Cyprinus carpio (Cyprinidae) exposed to ultraviolet radiation. Aquatic Toxicology 114$115,80-87$.

Stabili, I., Schirosi, R., Benedetto, A., Merendino, A., Villanova, L., Giangrande, A., 2011. First insights into the biochemistry of Sabella spallanzanii (Annelida: Polychaeta) mucus: a potentially unexplored resource for applicative purposes. Journal of the Marine Biological Association of the United Kingdom 91, 199-208.
Tiede, K., Hassellöv, M., Breitbarth, E., Chaudhry, Q., Boxall, A.B.A., 2009. Considerations for environmental fate and ecotoxicity testing to support environmental risk assessments for engineered nanoparticles. Journal of Chromatography A 1216, 503-509.

Trpkovic, A., Todorovic-Markovic, B., Trajkovic, V., 2012. Toxicity of pristine versus functionalized fullerenes: mechanisms of cell damage and the role of oxidative stress. Archives of Toxicology 86, 1809-1827.

Xie, B., Xu, Z., Guo, W., Li, Q., 2008. Impact of natural organic matter on the physicochemical properties of aqueous $\mathrm{C}_{60}$ nanoparticles. Environmental Science and Technology 42, 2853-2859.

Zar, J.H., 1984. Biostatistical Analysis. Prentice Hall, New Jersey, pp. 130-155.

Zhao, X., Striolo, A., Cummings, P.T., 2005. $\mathrm{C}_{60}$ binds to and deforms nucleotides. Biophysical Journal 89, 3856-3862.

Zhu, S.Q., Oberdörster, E., Haasch, M.L., 2006. Toxicity of an engineered nanoparticle (fullerene, $\mathrm{C}_{60}$ ) in two aquatic species, Daphnia and fathead minnow. Marine Environmental Research 62, S5-S9.

Zhu, X., Zhu, L., Lang, Y., Chen, Y., 2008. Oxidative stress and growth inhibition in the freshwater fish Carassius auratus induced by chronic exposure to sublethal fullerene aggregates. Environmental Toxicology and Chemistry 27, 1979-1985. 